\title{
BUŁGARZY W OBWODZIE ZAPOROSKIM NA UKRAINIE: TOŻSAMOŚĆ KULTUROWO-NARODOWA
}

\author{
HELENA KRASOWSKA
}

\begin{abstract}
Bulgarians in the Zaporizhzhia Oblast in Ukraine: the cultural-national identity The Zaporizhzhia oblast was created on 10 January 1939 as part of the Ukrainian Soviet Socialist Republic. As is generally known territories of this province were previously belonged to the Golden Horde and from 1554 year to the Crimean Khanate. From the XV to the XVII century northern part of Zaporozhzhia was the Zaporozhian Sich.

The presence of the Bulgarian minority living today on the territory of the Zaporizhzhia oblast dates back to the second half of the XIX century. In the years 1861-1862 the Bessarabian Bulgarians established in these areas 34 villages and the Bulgarians from Vidin established 2. There were established 36 Bulgarian villages, now remained 30

After 1990 the Bulgarian cultural societies were created, there are Bulgarian language courses on various levels, the Bulgarian-language press, the folk groups. Bulgaria educates in its universities Ukrainian students of Bulgarian origin, as well as delegates teachers of Bulgarian language to work here. Leaders of the Bulgarian associations are visible in the region and actively participate in the promotion of their own culture.
\end{abstract}

Autor: Helena Krasowska, Instytut Slawistyki PAN, ul. Bartoszewicza 1b/17, 00-337 Warszawa, e-mail: bukowinianka@wp.pl

Slowa kluczowe: Bułgarzy besarabscy, Bułgarzy widyńscy, obwód zaporoski, tożsamość, towarzystwa bułgarskie, język bułgarski

Keywords: Bessarabian Bulgarians, Bulgarians from Vidin, Zaporizhzhia oblast, identity, Bulgarian associations, Bulgarian language

Balcanica Posnaniensia. Acta et studia, XXIII, Poznań 2016, Wydawnictwo Instytutu Historii UAM, pp. 109118, ISBN 978-83-65663-26-9, ISSN 0239-4278. Polish text with a summary in English.

doi.org/10.14746/bp.2016.23.7

Przed przystąpieniem do właściwego tematu należy wprowadzić czytelnika w specyfikę regionu, jakim jest Zaporoże. Obwód zaporoski jest jednym z 24 obwodów Ukrainy. Leży w południowo-wschodniej części tego kraju nad dolnym Dnieprem. Jego południowe obrzeża znajdują się nad Morzem Azowskim. Długość linii brzegowej w granicach obwodu wynosi ponad $300 \mathrm{~km}$, a obszar obwodu $27180 \mathrm{~km}^{2}$, co stanowi 4,5\% terytorium Ukrainy. Jego stolicą jest miasto Zaporoże, które do 1921 roku nazywało się Aleksandrowsk.

Dzieje tego obszaru są skomplikowane. Przez wiele stuleci był to teren pograniczny, zamieszkały przez nieliczną koczowniczą ludność pasterską i na ogół słabo kontrolowany przez sąsiednie wielkie państwa. W XIII i XIV wieku należał do Złotej Ordy, 
a w drugiej połowie XIV wieku znalazł się w obrębie Wielkiego Księstwa Litewskiego. Do połowy XVI wieku był to teren niemal zupełnie niezamieszkały i nie kontrolowany przez nikogo, stanowiący szeroką buforową granicę ze Złotą Ordą, a później Chanatem Krymskim - „Dzikie Pola”, jak mówiono wówczas. Z czasem zaczęli go eksploatować Kozacy zajmujący się rybołówstwem, myślistwem i nierzadko rozbojem. W 1569 roku teren Zaporoża włączony został do Korony Polskiej. Jego sytuacja zmieniła się wówczas o tyle, że stał się on wentylem - miejscem schronienia dla ludności, która nie mogła sobie znaleźć miejsca w nowym systemie społecznym i politycznym powstałym po unii lubelskiej. W ten sposób powstała Sicz Zaporoska, która z czasem przekształciła się w centrum ukraińskiej świadomości narodowej. Po wybuchu powstania Bohdana Chmielnickiego w 1648 roku Sicz Zaporoska praktycznie usamodzielniła się, jednak po traktacie andruszowskim z 1667 roku weszła w skład państwa rosyjskiego, co potwierdził wieczny pokój polsko-rosyjski z roku 1686.

Po włączeniu do Rosji ziemie te cieszyły się początkowo względną autonomią, dość szybko jednak państwo rosyjskie podjęło kolonizację tego terenu. W 1752 roku w okolicach dzisiejszego Krzywego Rogu osiedlono grupę serbskich osadników wojskowych z terenu dzisiejszej Wojwodiny tworząc tzw. „Nową Serbię” istniejącą oficjalnie do roku 1764. Na zaproszenie Katarzyny II na terenie Zaporoża osiedlali się również Niemcy. W 1770 roku, w czasie wojny rosyjsko-tureckiej, zbudowano nad Dnieprem twierdzę Aleksandrowsk. Podporządkowanie przez Rosję, a później likwidacja Chanatu Krymskiego spowodowały, że twierdza ta szybko straciła znaczenie wojskowe.

W 1775 roku Aleksandrowsk należał do ujezdu konśkowodowskiego guberni azowskiej, od 1785 roku - do ujezdu nowomoskiewskiego, od 1797 roku - do ujezdu pawłogradskiego guberni noworosyskiej. W 1806 roku w gubernii jekaterynosławskiej został utworzony ujezd z centrum w Aleksandrowsku do którego włączono część ujezdów z mariupolskiego i pawłogradskiego ${ }^{1}$. Istotnych zmian po podziale tych jednostek do 1920 roku nie było.

W 1920 roku złożona z trzech ujezdów: melitopolskiego, aleksandrowskiego i berdiańskiego została utworzona gubernia aleksandrowska. W 1921 roku gubernia ta została przemianowana na zaporoską ${ }^{2}$. Do końca jej istnienia (1920-1922), w jej skład wchodziło sześć ujezdów: berdiański (ukr. Бердянський), wielkotokmacki (ukr. Великотокмацький), heniczeski (ukr. Генічеський), hulajpolski (ukr. Гуляйпільський), zaporoski (ukr. Запорізький), melitopolski (ukr. Мелітопольський). W grudniu 1922 roku gubernia zaporoska została zlikwidowana i włączona w skład guberni jekaterynosławskiej ${ }^{3}$.

W 1923 roku w związku z prowadzoną reformą administracyjną, z sześciu ujezdów byłej gubernii zaporoskiej, znajdujących się w składzie gubernii jekaterynosław-

\footnotetext{
1 Я. Новицкий, История г. Александровска, Екатеринослав 1905, s. 254.

2 Збірник узаконень і розпоряджень робітничо-селянського уряду Украӥни, 1921, nr 4, art. 135. art. 655 .

3 Збірник узаконень і розпоряджень робітничо-селянського уряду України, 1922, $\mathrm{nr} 44$,
} 
skiej utworzone zostały trzy okręgi: berdiański, zaporoski, melitopolski, a zamiast 130 włości - 36 rejonów. Do berdiańskiego okręgu weszło 9 rejonów, do zaporoskiego 12 rejonów, do melitopolskiego - 15. Od 1924 roku nadal były przeprowadzane zmiany wewnątrz rejonów, m.in. tworzono nowe rejony, a stare zmieniały nazwę oraz zmieniały się wówczas granice rejonów w celu utworzenia kolejnych.

W 1925 roku skasowane zostały gubernie ${ }^{4}$. Nastąpiło również przejście z czterostopniowego podziału administracyjnego do trzystopniowego, tzn. $z$ centrum-gubernia-powiat-włość na centrum-okręg-rejon. W związku z likwidacją guberni i przejściem na system trzystopniowy zmieniały się nazwy rejonów, powstawały nowe, zmieniały się też ich granice. W celu wzmocnienia władzy głównej jednostki rejonowej, w 1930 roku zostało wydane rozporządzenie O likwidacji okręgów i przejście na dwustopniowy system kierowania. Na podstawie tego rozporządzenia okręgi zaporoski i melitopolski zostały zlikwidowane. Od tego czasu aż do utworzenia obwodów rejony były podporządkowane bezpośrednio centrum jakie znajdowało się w Kijowie. Zaporoże jako jedno z 18 miast Ukraińskiej Radzieckiej Socjalistycznej Republiki zostało osobną jednostką administracyjno-terytorialną, podporządkowaną bezpośrednio władzom republiki w Kijowie. Pod koniec 1930 roku na terenie dawnego okręgu Zaporoskiego było 28 rejonów bezpośrednio podporządkowanych centrum.

W 1939 roku utworzono obwód zaporoski. W jego skład weszły również rejony z obwodów mikołajewskiego oraz dniepropietrowskiego ${ }^{5}$. W następnych latach rejony zmieniały swoje nazwy, odchodząc od nazw historycznych. Najczęściej nadawano im nazwy pochodzące od nazw miasteczek lub miast wywodzących się od nazw komunistycznych przywódców lub z przymiotnikiem красный tj. czerwony. Zmieniały się również granice tak samego obwodu, jak i jego rejonów. Granica obwodu zmieniła się po tym, jak w 1944 roku utworzono obwód chersoński do którego przeniesiono 6 rejonów z obwodu zaporoskiego. Odtąd do roku 1962 zmiany administracyjno-terytorialne następowały w ramach obwodu zaporoskiego i dotyczyły głównie granic rejonów. Po reformie administracyjnej przeprowadzonej w obwodach w 1962 roku zostało 10 rejonów, po kolejnej reformie w 1965 roku - było 17 rejonów ${ }^{6}$.

Od 1994 roku obwód zaporoski dzieli się na 20 rejonów. Zgodnie z ukraińskim podziałem administracyjnym 5 miast posiada status podporządkowania obwodowi: Zaporoże, Berdiańsk, Energodar, Melitopol, Tokmak; 9 miast ma status podporząd-

\footnotetext{
4 Збірник узаконень і розпоряджень робітничо-селянського уряду України, 1925, nr 29-30, art. 233.

5 «До складу Запорізької області включити такі райони Дніпропетровської області: м. Запоріжжя, Бердянський, Василівський, Велико-Білозерський, Велико-Токмацький, Веселівський, Генічеський,Гуляйпольський,Іванівський,Кам'янсько-Дніпровський,Коларовський,ім.В.В.Куйбишева, Люксембургський, Мелітопольський, Михайлівський, Молочанський, Нижнє-Сірогозький, НовоВасилівський, Ново-Златопольський, Ново-Миколаївський, Оріхівський, Приазовський, Ротфронтівський, Сивашський, Червоноармійський, Чернігівський, Пологський, Якимівський, Андріївський, та райони Миколаївської області: Велико-Лепетихський, Ново-Троїцький” w: https:/uk.wiki source.org/wiki/Про_утворення_Запорізької_області.

${ }^{6}$ Етнічні спільноти України. Довідник, Київ 2001, s. 64.
} 
kowania rejonowego: Wasylówka, Wilniańsk, Hulajpole, Dniprorudne, Kamionka Dnieprowska, Mołoczanśk, Orzechów, Połohy, Prymorśk; również są tu 22 osiedla typu miejskiego, 921 wsie, 263 rady wiejskie ${ }^{7}$.

Zaporoże jest miastem przemysłowym. W latach 1927-1932 powstała tu pierwsza wielka elektrownia wodna na Dnieprze, zwana Dniproges (ukr. ДніпроГЕC). W obwodzie rozwija się m.in. przemysł budowy maszyn, metalowy, hutnictwo żelaza i metali kolorowych, a także przemysł spożywczy i lekki. Zgodnie z podziałem na regiony gospodarcze obwód zaporoski wraz z obwodem dniepropietrowskim tworzą dobrze rozwinięty gospodarczo region naddnieprzański.

Skomplikowana historia tego obszaru, częste zmiany przynależności państwowej, a później administracyjnej, wreszcie powstanie wielkich ośrodków przemysłowych nie pozostawały bez wpływu na sytuację demograficzną i etniczną.

Od drugiej połowy lat osiemdziesiątych XVII w., obok ludności kozackiej różnego pochodzenia etnicznego rozpoczęła się intensywna kolonizacja tego obszaru przez przybyszów z innych terenów Rosji, jak też spoza jej obszaru: Serbów, Greków, Polaków, Żydów, Niemców, Bułgarów, Mołdawian, Rosjan-staroobrzędowców8 Powstanie wielkiego przemysłu ściągnęło tam specjalistów i robotników z całego Związku Radzieckiego, w dużej części Rosjan. Spowodowało to dużą mozaikę etniczną i narodowościową. $Z$ drugiej strony dość szybko następowały procesy asymilacyjne w kierunku nacji dominującej politycznie, bądź liczebnie. Możemy to zaobserwować porównując stosunki procentowe grup narodowościowych w obwodzie zaporoskim w latach 1989 i 2001:

Liczba ludności w obwodzie zaporoskim w \%

\begin{tabular}{|l|r|r|}
\hline \multicolumn{1}{|c|}{ Narodowość } & 1989 & 2001 \\
\hline Ukraińcy & 63,1 & 70,8 \\
Rosjanie & 32,0 & 24,7 \\
Bułgarzy & 1,7 & 1,4 \\
Białorusini & 0,9 & 0,7 \\
Grecy & 0,1 & 0,1 \\
Żydzi & 0,7 & 0,2 \\
Tatarzy & 0,3 & 0,3 \\
Ormianie & 0,1 & 0,3 \\
Niemcy & 0,1 & 0,1 \\
Polacy & 0,1 & 0,1 \\
Inni & 0,9 & 1,3 \\
\hline
\end{tabular}

\footnotetext{
${ }^{7}$ https://uk.wikisource.org/wiki/Про_утворення_Запорізької_області [dostęp: 15.08.2016].

${ }^{8}$ N. Jakowenko, Historia Ukrainy. Od czasów najdawniejszych do końca XVIII wieku, Lublin 2000, s. 366 .
} 
Można zauważyć, że w ciągu 12 lat zmniejszyła się o 7,3\% liczba osób przyznających się do narodowości rosyjskiej. Jednocześnie widać wzrost liczby Ukraińców w obwodzie w zaporoskim - o 7,7\%. Zmalała też liczba mniej licznych nacji: Bułgarów, Białorusinów, Żydów. Mogło to być skutkiem budzenia się świadomości ukraińskiej, jak też migracji związanych z rozpadem Związku Radzieckiego i powstaniem państw narodowych.

Pociesza jedynie fakt, że nadal istnieje w tym regionie wielonarodowość i wielokulturowość, wyraźnie widać, że zjawiska te mają tendencję wzrostową. Należy się spodziewać, że przy okazji następnego spisu ludności przedstawiciele poszczególnych narodowości nie będą się bać i zadeklarują swą narodowość nie taką, jaka wpisana została do dowodu osobistego, czyli ukraińską, lecz taką, jaką rzeczywiście uważają za swoją. W 2001 roku w obwodzie zaporoskim mieszkało 130 różnych grup etnicznych i narodowych. Wśród nich do ciekawszych i trochę lepiej zorganizowanych zaliczyć należy mniejszość bułgarską.

Obecność mniejszości bułgarskiej zamieszkującej dziś na terytorium obwodu zaporoskiego sięga drugiej połowy XIX w. W latach 1861-1862 Bułgarzy besarabscy założyli na tych terenach 34 wsie, a Bułgarzy widyńscy -2 . Z założonych 36 wiosek bułgarskich do dzisiejszego dnia zachowało się $30^{9}$.

Zgodnie z postanowieniami układu pokojowego w Paryżu z 1856 roku, kończącego wojnę krymską, południowa część Besarabii zamieszkała także przez liczną ludność bułgarską została odłączona od Rosji i przyłączona do Księstwa Mołdawskiego. Bułgarzy źle się czuli w rumuńskojęzycznym państwie, którego języka często nie znali, popadali w konflikty z miejscowymi urzędnikami, pogarszała się ich ogólna sytuacja życiowa. Zwrócili się więc do Rosji z prośbą o ponowne przyjęcie ich jako osadników w granice państwa rosyjskiego. Otrzymali wówczas możliwość przesiedlenia się do guberni jekaterynosławskiej, na tereny dzisiejszego obwodu zaporoskiego. Besarabscy Bułgarzy na nowo osiedlonych ziemiach otrzymali pomoc pieniężną, ziemię, a także zwolnienie od podatków na okres 8 lat - podobnie jak i inni osiedleńcy. Osiedliło się tu wówczas około 3,5 tysiąca rodzin (17,5 tysiące osób). Masowe przesiedlenie Bułgarów besarabskich zakończyło się jesienią 1862 roku, aczkolwiek

${ }^{9}$ С. Пачев, Приазовські болгари: проблема збереження культурної спадщини, [w:] Держсавна етнонаціональна політика: правовий та культурологічний аспекти в умовах Півдня України, Запоріжжя 2003, s. 71; С. Пачев, Возникновение болгарских сел в Северном Приазовье (1861-1863), Мелитополь 2007, ss. 88 - autor opisuje osiedlenie się Bułgarów w ujazdach berdiańskim i melitopolskim (gubernia taurydzka). Główne kierunki migracji pochodziły z Besarabii oraz północno-zachodniej Bułgarii w latach 1861-1862. W wyniku tych migracji powstały bułgarskie wsie na terytorium dzisiejszego obwodu zaporoskiego. Autor jest Bułgarem, jednym z najaktywniejszych liderów w tym regionie, prezesem Stowarzyszenia Bułgarskiej Kultury „Bałkany” w Melitopolu. Por. też B.I., Мільчев, Болгарські переселенці на півдні Украӥни 1724-1800, Київ-Запоріжжя 2001; В.М. Чоп, Участь болгарських колоністів приазов"я в повстанському русі 1919-1921 pp. [w:] Державна етнонаціональна політика: правовий та культурологічний аспекти в умовах Півдня України, Запоріжжя 2003, s. 92-96; В. Митков, Болгары на Запорожской земле: Страницы истории и культуры, Запорожье 2007; В. Митков, Голгофа болгар Таврии: анатомия репрессий (1920-е - 1940-е годы), Запорожье 2009. 
znane są też fakty przesiedleń późniejszych, były one jednak mało znaczące, dotyczyły kilku pojedynczych rodzin.

Druga fala migracji Bułgarów miała miejsce w latach 1861-1863. Tym razem osadnicy pochodzili z Widynia w północno-zachodniej Bułgarii. Powodem migracji był kryzys społeczno-ekonomiczny w tym regionie wywołany osiedleniem się tam muzułmanów, którzy wyemigrowali z Rosji w 1860 roku. Bułgarzy zdecydowali się wówczas poszukać dla siebie nowych miejsc zamieszkania. Pozwolono im osiedlić się na terenach obecnego obwodu zaporoskiego, jednak w odróżnieniu od swoich ziomków z Besarabii nie otrzymali oni pełni praw kolonistów cudzoziemskich, lecz tylko małe działki ziemi, natomiast zostali zwolnieni ze służby wojskowej i podatków na 8 lat, otrzymali też jednorazową pomoc finansową.

Bułgarzy zamieszkiwali początkowo przeważnie na wsi w zwartych grupach. Urbanizacja regionu wpłynęła na ich sytuację, z czasem zaczęli oni migrować do miast. Według spisu ludności z 1989 roku, aż 47,9\% bułgarskiej mniejszości w obwodzie zaporoskim było mieszkańcami miast ${ }^{10}$. Dynamika wzrostu liczby przedstawicieli tej narodowości po osiedleniu się na terenach południowej Ukrainy była zrazu bardzo duża. Do 1914 roku liczba Bułgarów wzrosła trzykrotnie i wynosiła 45000. Później, na skutek strat demograficznych spowodowanych pierwszą wojną światową, wielkim głodem (1921-22 i 1932-33), represjami stalinowskimi liczba ta zmniejszyła się. Niewiele wzrosła po drugiej wojnie światowej i w 1979 roku wynosiła już tylko 37,1 tysięcy. Gwałtowny spadek obserwujemy jednak na przełomie XX i XXI wieku. Spis ludności z 1989 roku podaje 43,6 tysięcy ludności bułgarskiej w obwodzie zaporoskim $^{11}$, a z roku 2001 zaledwie $27764^{12}$.

Spadek liczebności osób narodowości bułgarskiej thumaczy się dwojako: brakiem nowych kolonistów i asymilacją. Badacze kultury bułgarskiej thumaczą fakt asymilacji zawieraniem małżeństw z osobami innych narodowości, brakiem szkolnictwa, brakiem warunków dla rozwoju narodowej kultury, który odpowiadałby współczesnym wymogom. Uwagę również zwraca tendencja do rusyfikacji istniejąca w XX wieku m.in. w środowisku Bułgarów. W 1979 roku 70\% ich wymieniło język rosyjski jako ojczysty, w 1989 roku 50\% - uznało język rosyjski za ojczysty ${ }^{13}$. Około $50 \%$ Bułgarów mieszka obecnie $\mathrm{w}$ innojęzycznym otoczeniu: rosyjskim i ukraińskim, nadal ulegając procesom asymilacyjnym.

Spis ludności z 2001 roku, podaje, że na całej Ukrainie Bułgarów jest 204 574, spośród nich $64,2 \%$ język bułgarski uważa za swój język. W obwodzie donieckim mieszka 4833 Bułgarów, w zaporoskim - 27 764; najwięcej Bułgarów zamieszkuje

10 Численность населения Запорожской области (по данным Всесоюзной переписи населения 1989 г.), Запорожье 1991, s. 126-128.

${ }^{11}$ Ibidem, s. 126.

12 Україна поліетнічна, упорядники І. Винниченко, Л. Лойко, Київ 2003, s. 27.

13 Численность населения Запорожской области (по данным Всесоюзной переписи населения 1989 г.), Запорожье 1991, s. 140. 
obwód odeski - 150 683. Mieszkają oni również w obwodach: dniepropietrowskim, kirowogradskim, lugańskim, charkowskim, chersońskim i na Krymie ${ }^{14}$.

Wskaźniki tożsamości. W obwodzie zaporoskim zarejestrowane są i działają: Zaporoskie Obwodowe Towarzystwo Kultury Bułgarskiej (1991 data rejestracji), Zaporoskie Miejskie Bułgarskie Towarzystwo „Rodzina” (1996), Zaporoska Miejska Bułgarska Spółka 'Cyryl i Metody' (2000), Przymorskie Bułgarskie Towarzystwo „Співдружність”, Melitopolskie Towarzystwo Bułgarskiej Kultury „Bałkany”(1995), Berdiańskie Towarzystwo Bułgarskiej Kultury 'Rodolubije' (1991). Działalność owych Towarzystw skupiona jest na odradzaniu i kontynuowaniu kultury bułgarskiej na Zaporożu. Od ich liderów zależy rozwój owych Towarzystw, ich działalność oraz aktywność w prezentacji bułgarskiej kultury na całej Ukrainie. Pielęgnowanie bulgarskich tradycji wyróżnia ich spomiędzy pozostałych mieszkańców tego regionu. Zakładane są i działają zespoły folklorystyczne promujące kulturę bułgarską. Bułgarska działalność folklorystyczna oraz kulinarna znana jest innym mniejszościom w regionie. Obok innych mniejszości etnicznych i narodowych wzbogacają oni pejzaż kulturowy nie tylko regionu, ale całej Ukrainy.

Ważnym zadaniem ośrodków bułgarskich jest także nauczanie języka bułgarskiego, oraz doskonalenie wiedzy o przeszłości i teraźniejszości Bułgarii. Język bułgarski wykładany jest na uczelniach wyższych, są prowadzone seminaria, sesje, naukowe konferencje poświęcone kulturze i językowi bułgarskiemu w regionie. W 2014 roku Państwowy Uniwersytet Pedagogiczny w Berdiańsku zorganizował III Międzynarodowe Seminarium na temat bułgarskiego języka, literatury, kultury i historii. Problemy poruszane na seminarium to: historia bułgarskiego języka literackiego, bułgarska dialektologia, współczesny język bułgarski, język bułgarski: aspekty tłumaczeniowe, specyfika nauczania języka bułgarskiego jako obcego, język bułgarski w systemie szkolnym, historia literatury bułgarskiej, historia Bułgarii, bułgarystyka za granicą, folklor i etnologia. Odbywają się także seminaria dokształcające nauczycieli języka bułgarskiego.

Alla Karanukh przedstawiła wyniki badań na temat tożsamości etnicznej Bułgarów Berdiańska i wsi Zelenówka w rejonie Primorska. Pisze ona „Wśród wypowiedzi przedstawicieli pokolenia powojennego wyłaniają się dwa dominujące wątki: z jednej strony podkreślane jest bułgarskie pochodzenie etniczne jako swoista duma z posiadanych korzeni, z drugiej zaś strony, w zależności od wielu czynników wewnętrznych lub zewnętrznych, identyfikacja narodowa/państwowa jest ukazywana poprzez „kosmopolityzm” lub inaczej „internacjonalizm” w kierunku identyfikacji podwójnej. W przypadku ukraińskich Bułgarów ważna jest nie tylko identyfikacja z narodem ukraińskim, ale również sposób, w jaki pojmują przynależność do grupy etnicznej"15. Bułgarzy w obwodzie zaporoskim nostalgiczne wracają do lat minionych, do lat dzieciństwa i czasów młodości. Niestety łączy ich piętno radzieckości, często nie-

14 Україна поліетнічна, упорядники І. Винниченко, Л. Лойко, Київ 2003, s. 17.

${ }^{15}$ A. Karnaukh, Pomiędzy ukraińskościq a sowieckościa. Ukraińcy, Rosjanie i Bułgarzy na Zaporożu, Kraków, 2015, s. 181. 
uświadamiane lub negowane, ale przejawiające się raz po raz w różnych sytuacjach. Współczesny dyskurs mniejszości etnicznych i narodowych w tej części Ukrainy opisuje postradziecki typ osobowości w kontekście traumy zbiorowej i kryzysu tożsamości. O ile Polacy w tym regionie określają wskaźniki ich tożsamości, o tyle Bułgarzy odwołują się do 'człowieka-sowieckiego', 'wszyscy tu my pomieszani', 'my sowieckije', ale także występują takie określenia jak: 'z mieszaną krwią', 'w paszporcie mąż jest Bułgarem'. Kryteria subiektywne które dało się zaobserwować w rozmowach z osobami o identyfikacji bułgarskiej to głównie: kryterium więzi krwi oraz kryterium dokumentów i adnotacji urzędowych, wynikające jednak z więzów krwi.

U nas babuszka była botgarkoj i dieduszka, czistaja botgarskaja krow, a potom uże papa bojalsia i stat ruskim w pasportie. Byt botgarom, potomu szczto on czistokrownyj botgar [Wywiad 2009: Berdiańsk].

W stosunku do mniejszości bułgarskiej A. Karnaukh wyróżnia dwa podstawowe typy tożsamości:

„I. „Jestem Ukraińcem (w sensie przynależności państwowej) języka rosyjskiego, o pochodzeniu etnicznym" - co należy uznać za tożsamość obywatelską (cztery osoby).

II. „Jestem tutejszym Bułgarem, człowiekiem sowieckim, mieszkańcem Ukrainy" - co sytuuje się pomiędzy tożsamością lokalną a tożsamością sowiecką (dwie osoby)"16.

Wybór jednoznacznej identyfikacji jest bardzo trudny, nakładają się kryteria w następujący sposób: państwowość-język-przynależność do grupy, lub wybór tej przynależności. Warto zauważyć, że kryterium religijne nie odgrywa tu znaczącej roli, ponieważ prawosławie wyznają także inne grupy narodowe i etniczne w tym regionie. Wyznanie dla Bułgarów nie stanowi wyróżnika tożsamości bułgarskiej.

Kryterium językowe spotkani Bułgarzy określają następująco: bołgarskuju mowu my nie znajem; bolgarskij jazyk ja nie styszała, mama była botgarkoj no na ruskom razgawariwała; pojem tolko piesni botgarskije; nie nie znaju botgarskogo jęzka; jeśli nie znaju bolgarskogo języka, to ja i nie botgarka, a roditieli u mienia botgary itd.

W sferze rodzinnej oraz sąsiedzkiej nikt nie używa języka bułgarskiego czy raczej odmiany dialektalnej tego języka. W analizie języka codziennej komunikacji środowiska rodzinnego Bułgarów należy uwzględnić uwarunkowania tej społeczności, która znajduje się wśród innych grup narodowościowych, dla których spoiwem był i nadal pozostaje język rosyjski. Do istotnych uwarunkowań zaliczam: rozproszenie grupy bułgarskiej, zawieranie mieszanych małżeństw; rosyjskojęzyczne otoczenie. Przyczyną takiego stanu rzeczy jest nie tylko etniczna struktura ludności tego regionu, ale również praktykowana i narzucana przez władze polityka językowa oraz wynikające z tej polityki funkcje każdego z używanych języków, ich prestiż i zakres użycia.

${ }^{16}$ A. Karnaukh, ibidem, s. 187. 
Podsumowując, można stwierdzić, że na terytorium południowo-wschodniej Ukrainy od dawna zamieszkiwali przedstawiciele różnych narodów, kultur i tradycji. Był to więc region charakteryzujący się przenikaniem wzajemnych wpływów. Warto zaznaczyć, że głównie od XVIII wieku odbywała się kolonizacja tych terenów przez przesiedleńców-cudzoziemców, którzy wnieśli największy wkład kulturowy i przemysłowy w rozwój tego regionu. W większości osiedlali się oni w zwartych grupach (osadach, wsiach) - co sprzyjało ich szybkiemu wzrostowi. Industrializacja, a następnie „stalinizacja” regionu powodowała likwidację części grup narodowościowych, $\mathrm{i}$ ich asymilację co miało doprowadzić do jedynego języka, tj. rosyjskiego i jedynego narodu tj. ,radzieckiego”. Na skutek tego dzisiejsze oblicze regionu jest językowo dosyć jednolite, głownie rosyjskojęzyczne. W rezultacie przemian politycznych po 1991 roku da się zauważyć, że region nabiera znowu charakteru wielokulturowego, w którym Bułgarzy poprzez swoje działania znacznie odróżniają się od innych grup etnicznych i narodowych oraz wnoszą znaczny wkład w rozwój kulturowy całego regionu.

Sytuacja mniejszości bułgarskiej poprawiła się nieco po 1990 roku, kiedy powstały bułgarskie towarzystwa kulturowe, w różnym stopniu jest nauczany język bułgarski, w języku bułgarskim wydawana jest prasa, są zespoły folklorystyczne. Bułgaria kształci na uczelniach wyższych studentów pochodzenia bułgarskiego z Ukrainy, a także deleguje tu do pracy nauczycieli języka bułgarskiego. Liderzy bułgarskich stowarzyszeń są widoczni w regionie i aktywnie biorą udział w promocji własnej kultury. A oto jedna z wypowiedzi:

Nas w Zaporoskoj oblasti mnogo. W gorodach mnogije ludi prosto zabyli szczo oni, ich raditieli, dieduszki i babuszki - bolgary. My dielajem wsio, sztob pokazat'swoju kulturu. U nas swai tancy, piesni, my zanimajemsia naucznymi rabotami i isliedowanijami bolgar $w$ regionie. My starajemsia derżatsia wmiestie. Choroszo, czto uże my sozdali obszczestwo i możem spokojno rabotat' dla nas bolgar, na blago naszej Ukrainy i Bolgarii [Melitopol 2007: wywiad].

\section{BIBLIOGRAFIA:}

Alla Karnaukh, Pomiędzy ukraińskościq a sowieckościq. Ukraińcy, Rosjanie i Bułgarzy na Zaporożu, wyd. NOMOS, Kraków, 2015.

Сергій Пачев, Возникновение болгарских сел в Северном Приазовье (1861-1863), wyd. «Издательский дом МГТ», Мелитополь, 2007.

Сергій Пачев, Приазовські болгари: проблема збереження культурної спадщиии, w: Державна етнонаціональна політика: правовий та культурологічний аспекти в умовах Півдня Украӥни, wyd. Сімферополь: Доля, Запоріжжя, 2003.

Natalia Jakowenko, Historia Ukrainy. Od czasów najdawniejszych do końca XVIII wieku, Instytut Europy Środkowo-Wschodniej, Lublin, 2000.

Piotr Eberhardt, Przemiany narodowościowe na Ukrainie XX wieku,wyd. Obóz, Warszawa, 1994.

Борис Михайлов, Мелитополь. Природа, археология, история, wуd. «Дикое Поле», Запорожье, 2006.

Василий Митков, Болгары на Запорожской земле: Странищы истории и культуры, wyd. «Тандем - У», Запорожье, 2007. 
Василий Митков, Голгофа болгар Таврии: анатомия репрессий (1920-е - 1940-е годы), wyd. «Тандем - У», Запорожье, 2009.

Владимир Супруненко, Запорожский край, wyd. «Просвіта», Запоріжжя, 2007.

Етнічні спільноти Украӥни. Довідник, wуd. «Фенікс», Київ, 2001.

Народи Північного Приазов'я (етнічний склад та особливості побутової культури), wyd. «Просвіта», Запоріжжя, 1997.

Україна поліетнічна: інформаційно-бібліографічний покажчик, упорядники І. Винниченко, Л. Лойко, wyd. «Геопринт», Київ, 2003.

Яков Новицкий, История г. Александровска, wyd. «Типография Губернского Земства», Екатеринослав, 1905. 